\title{
Distribution of bioluminescent fungi across old-growth and secondary tropical rain forest in Costa Rica
}

\author{
Carolina Seas-Carvajal ${ }^{1} \&$ Gerardo Avalos ${ }^{1,2}$ \\ 1. Escuela de Biología, Universidad de Costa Rica, 2060 San José, Costa Rica; carolina.seas@ucr.ac.cr \\ 2. The School for Field Studies, Center for Sustainable Development Studies, 10 Federal St., Salem, MA 01970 USA; \\ gerardo.avalos@ucr.ac.cr
}

Received 25-I-2012. C Corrected 20-IX-2012. Accepted 22-X-2012.

\begin{abstract}
Most research on bioluminescent fungi is concentrated on their taxonomic relationships, while the basics of their natural history and ecological relationships are poorly understood. In this study, we compared the distribution of bioluminescent fungi between old-growth and secondary forest as related to four different soil types at the tropical rainforest of La Selva Biological Station in Costa Rica. The study was conducted during the wet season of 2009. Bioluminescent fungi were sought following eight different transects distributed evenly in old-growth and secondary forests across four different soil types, covering an area of $9420 \mathrm{~m}^{2}$. We found fungi in four different substrates: litter, fallen branches, dead trunks, and roots, for a total of 61 samples. Correspondence analysis showed that the occurrence of fungi and soil types were related (inertia $=0.21, \mathrm{p}=0.071$ ). We found a significant relationship between the presence of fungi and the distribution of soil types $\left(X^{2}=18.89, \mathrm{df}=9, \mathrm{p}=0.026\right)$. We found only three samples with fruiting bodies, two of which had Mycena and the other had one fungus of the order Xylariales (possibly Hypoxylon sp., Kretzschmariella sp., Xylaria sp.). Future work will concentrate on exploring other aspects of their ecology, such as their dispersal and substrate preference. This information will facilitate field identification and will foster more research on the distribution, seasonality, reproductive phenology and ecological requirements of this group of Fungi. Rev. Biol. Trop. 61 (2): 531-537. Epub 2013 June 01.
\end{abstract}

Key words: bioluminescence fungi, Costa Rica, La Selva, Mycena, tropical rain forest.

Bioluminescent organisms are diverse and extensively distributed among many groups including bacteria, dinoflagellates, insects and fungi. Bioluminescence refers to the emission of visible light by living organisms mediated by an enzyme-catalyzed (luciferase) reaction of oxygen with a substrate (luciferin). Luciferases do not show homology relative to each other; and luciferins are chemically and phylogenetically unrelated (Weitz 2004). Molecular oxygen is the only common feature of bioluminescent reactions, showing that luminescent systems in most organisms may have evolved independently (Wilson \& Hastings 1998).

Many reasons for the role of bioluminescence in fungi have been suggested. Some of these hypotheses suggest that luminescence helps to attract invertebrates to assist in spore dispersal (Sivinski 1981, 1998). Other hypotheses suggest that bioluminescence excludes negatively phototropic fungivores, or can even work as a warning signal to nocturnal fungivores (Sivinski 1998). Tentative explanations indicate that bioluminescence is a by-product of a biochemical reaction, and that it has no ecological role (Weitz 2004). There is only limited evidence in support of each of these hypotheses, due to the paucity of actual field evidence (Weitz 2004).

Luminous fungi belong to the phylum Basidiomycota, and are found in tropical as well as temperate climates, always associated with hydrated substrates, with the possible exception of the ascomycete Xylaria hypoxylon (Foerster et al. 1965). They emit a greenish, cold light with a maximum intensity 
of 520-530nm (O'Kane et al. 1990). It is not known whether the biochemistry of bioluminescence in fungi is the same as in other bioluminescent groups, such as bacteria, unicellular algae, coelenterates, beetles, fishes and others (Wilson \& Hastings 1998).

Relatively little research has been conducted on bioluminescent fungi. There are currently more than 64 species in three distinct lineages: Ompholatus, Armillaria and mycenoid (Desjardin et al. 2008). Examples of luminescent mushrooms include Armillaria mellea, Mycena citricolor and Omphalotus olearius. Panellus stipticus is unusual in that luminescence is exhibited only by the North American strains and not by the Eurasian ones (Peterson \& Bermudes 1992). Luminescence may occur in both mycelia and fruiting bodies, like in P. stipticus and O. olearius; or only in mycelia and young rhizomorphs, as in $\mathrm{A}$. mellea (Herring 1994 in Weitz 2004). However, there have been very few ecological studies of bioluminescent fungi, and no examination of their distribution and substrate requirements across different habitat types in tropical regions. Only a few studies of bioluminescent fungi have been carried out in the tropics. One study in Panama examined how bioluminescence characteristics were affected by temperature, humidity, and exposure to light, but the species was not identified (Deheyn 2007). A group of researchers in Brazil recently discovered a new species of bioluminescent fungus of the genus Gerronema (Desjardin et al. 2005), and are in the process of describing several others species (Desjardin et al. 2007, Capelari et al. 2011). Our study aims to add to this growing body of knowledge by comparing the distribution of bioluminescent fungi across successional and soil gradients considering old-growth and secondary forests and four different soil types. Understanding the physical conditions that affect the distribution and abundance of bioluminescent fungi will provide insights for determining the role that these organisms play across successional stages.

\section{MATERIALS AND METHODS}

Study site: The study was conducted during the wet season (June-August) of 2009 at

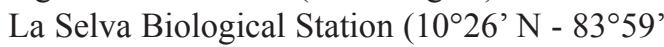
W), Sarapiquí, Heredia, Costa Rica. La Selva comprises 1600 ha of tropical wet forests, with an annual rainfall and temperature average of $3800 \mathrm{~mm}$ and $26^{\circ} \mathrm{C}$, respectively (not a single month receives less than $100 \mathrm{~mm}$; McDade \& Hartshorn 1994). Altitude varies from approximately $30 \mathrm{~m}$ to $150 \mathrm{~m}$ (Matlock \& Hartshorn 1999). The landscape is of volcanic origin, and the topography varies from flat, alluvial terraces to moderately undulating hills derived from Pleistocene lava flows (McDade \& Hartshorn 1994). The soils are deep inceptisols, and despite their young age, are generally rock-free and fairly rich in organic matter (Lieberman \& Lieberman 1987).

Collection of fungal samples: Mycelia of bioluminescent fungi were collected by hand at night along eight $325 \mathrm{~m}$ long transects, distributed evenly in old-growth and secondary forests taking into account four different soil types: Andic Humitropept (AH), Typic Tropohumult (TT), Typic Humitropept (TH) and Andic Dystropept (AD) according to the original version of Soil Taxonomy (USDA Soil Survey Staff 1975 in Sancho \& Mata 1987, McDade \& Hartshorn 1994). At every $25 \mathrm{~m}$ along the transect, we turned off all lights and searched for bioluminescent fungi within a $5 \mathrm{~m}$ radius. We surveyed each transect 15 times. The fungi were collected from decaying pieces of wood or leaves showing bright bioluminescence and then were placed in clean wax paper envelopes.

We also surveyed each of the transects twice during the day to search for fruiting bodies, once in the morning following the night survey, and again three days later. When fruiting bodies were found, the samples were placed in clean wax paper envelopes and taken to a dark room to confirm the presence of bioluminescence. Species were described using the diagnostic features of their fruiting bodies, considering traits such as the pileus, context, 
lamellae and stipe among other morphological characters (Mueller et al. 2004).

To determine the degree of association between fungal substrates, forest successional stages, and soil type we applied a correspondence analysis. A logistic regression was used to measure the effects of forest and soil type on the probability of belonging to a particular substrate category. All analyses were performed using JMP 7.0 statistical software.

\section{RESULTS}

Collection of fungal samples: One hundred and twenty survey points were sampled in the eight transects, 60 per forest type, and 15 per soil type, covering a total area of 9 $420 \mathrm{~m}^{2}$. We found fungi only at 21 sampling stations in four different substrates: litter, fallen branches, dead trunks, and roots, for a total of 61 samples. The transect in the old-growth forest on AD soil type presented the most bioluminescent fungi, followed by the transect in the secondary forest on TH soil type. Decomposing organic matter (dead trunks and litter) was the preferred substrate used by bioluminescent fungi (Table 1, Fig. 2E, 2F).

The correspondence analysis did not show a clear association between the different substrates and forest types (inertia $=0.069$ ). There was, however, a significant association between fungus substrate and soil type. In this case, dead trunks and roots were associated with TT and AD soils, whereas fallen branches were associated with $\mathrm{AH}$, and litter was associated with TH (Fig. 1), explaining the variation across two axes (inertia values $=0.21,0.071$ ).

The results of the logistic regression show that the interaction of forest successional stage and soil type explained the distribution of fungi on the different substrate categories $\left(\mathrm{X}^{2}=23.21\right.$, $\mathrm{df}=12, \mathrm{p}=0.025)$. Forest type by itself did not explain the distribution of bioluminescent fungi in these four substrates $\left(\mathrm{X}^{2}=6.08, \mathrm{df}=3\right.$, $\mathrm{p}=0.10$ ), whereas soil type had a relevant effect on the probability of fungi occurrence in different substrate categories $\left(X^{2}=18.89\right.$, $\mathrm{df}=9, \mathrm{p}=0.026$ ).

Field records: Only three samples had fruiting bodies; two samples had Mycena s.l., and the other had a fungus belonging to the order Xylariales (possibly Hypoxylon sp., Kretzschmariella sp., Xylaria sp.). The description of the samples with fruiting bodies is as follows:

Mycena s.l. 1. Pileus: $0.8-3.0 \mathrm{~cm}$ diameter, slightly umbilicate, surface striated and translucent toward the margin, striated margin, light brown color. Context: less than $0.1 \mathrm{~cm}$, concolor with the pileus. Hymenium: lamellae free, subdistant, with three different size lamellulae. Stipe: $1-1.5 \mathrm{~cm}$ long and $1-2 \mathrm{~mm}$ wide, cylindric, position central, surface fibrillose, concolor with the pileus. Ocurrence: gregarious. Substrate: growing on wood. Habitat: Old-Growth forest, AD soil, sendero Atajo.

TABLE 1

Distribution of bioluminescent fungi across four different substrates and successional stages at La Selva Biological Station, July 2009

\begin{tabular}{|c|c|c|c|c|c|c|c|c|c|}
\hline \multirow{2}{*}{ Substrates } & \multicolumn{4}{|c|}{ Old-Growth Forest } & \multicolumn{4}{|c|}{ Secondary Forest } & \multirow{2}{*}{ Total } \\
\hline & $\mathrm{AH}^{*}$ & $\mathrm{TT}^{*}$ & $\mathrm{TH}^{*}$ & $\mathrm{AD}^{*}$ & $\mathrm{AH}^{*}$ & $\mathrm{TT}^{*}$ & $\mathrm{TH}^{*}$ & $\mathrm{AD}^{*}$ & \\
\hline Litter & 3 & 1 & 2 & 4 & 0 & 0 & 5 & 0 & 15 \\
\hline Fallen branches & 2 & 0 & 1 & 3 & 2 & 1 & 0 & 0 & 9 \\
\hline Dead trunks & 1 & 6 & 1 & 8 & 0 & 3 & 6 & 4 & 29 \\
\hline Roots & 0 & 0 & 0 & 2 & 0 & 2 & 3 & 1 & 8 \\
\hline Total & 6 & 7 & 4 & 17 & 2 & 6 & 14 & 5 & 61 \\
\hline
\end{tabular}

\footnotetext{
* For abbreviations see Materials and Methods.
} 


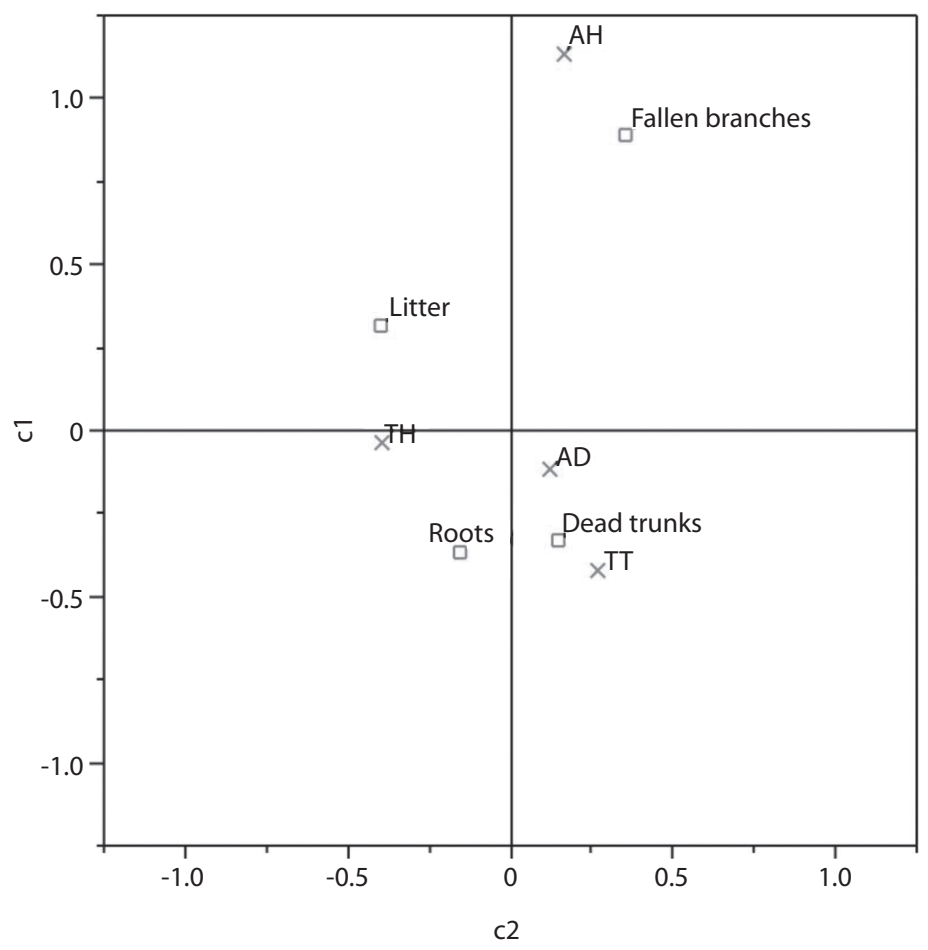

Fig. 1. Correspondence analysis showing the distribution of bioluminescent fungi according to substrate and soil type at La Selva Biological Station, July 2009. For abbreviations see Materials and Methods.

Location: survey point at $25 \mathrm{~m}$ and $125 \mathrm{~m}$ from trail head (Fig. 2A, 2B).

Mycena s.l. 2. Pileus: $2.0-5.0 \mathrm{~mm}$ diameter, slightly umbilicate, surface striated and translucent toward the margin, striated margin, light brown color. Context: less than $0.1 \mathrm{~cm}$, concolor with the pileus. Hymenium: lamellae free, subdistant, with three different size lamellulae. Stipe: $1.0-1.5 \mathrm{~cm}$ long and $1-2 \mathrm{~mm}$ wide, cylindric, position central, surface fibrillose, concolor with the pileus. Ocurrence: gregarious. Substrate: growing on wood. Habitat: Old-Growth forest, TT soil, sendero Surá. Location: survey point at $1000 \mathrm{~m}$ from trail head (Fig. 2C, D).

Order Xylariales (possibly Hypoxylon sp., Kretzschmariella sp., Xylaria sp.). These were found growing in roots of the palm Geonoma congesta in old-growth forest and
TT soil, sendero Surá survey point at $1025 \mathrm{~m}$ from trail head.

Additional observations: Although most of the bioluminescent fungi were found growing on decaying wood, those that were growing on decomposing trunks or roots were frequently found on leaves and trunks of palms, as well as trees of Fabaceae (Mimosaceae), and lianas. We also searched for luminescent mycelia, but it was not possible to identify the hyphal development. We did observe that wood with bioluminescent mycelia was always orange in color and the luminescence was brighter on transects closer to streams.

On each of the three samples with fruiting bodies, unidentified insects were present. This potentially supports the hypothesis that bioluminescence serves to attract insects for spore dispersal, although more studies are needed. A few samples with fungi colonizing wood were 

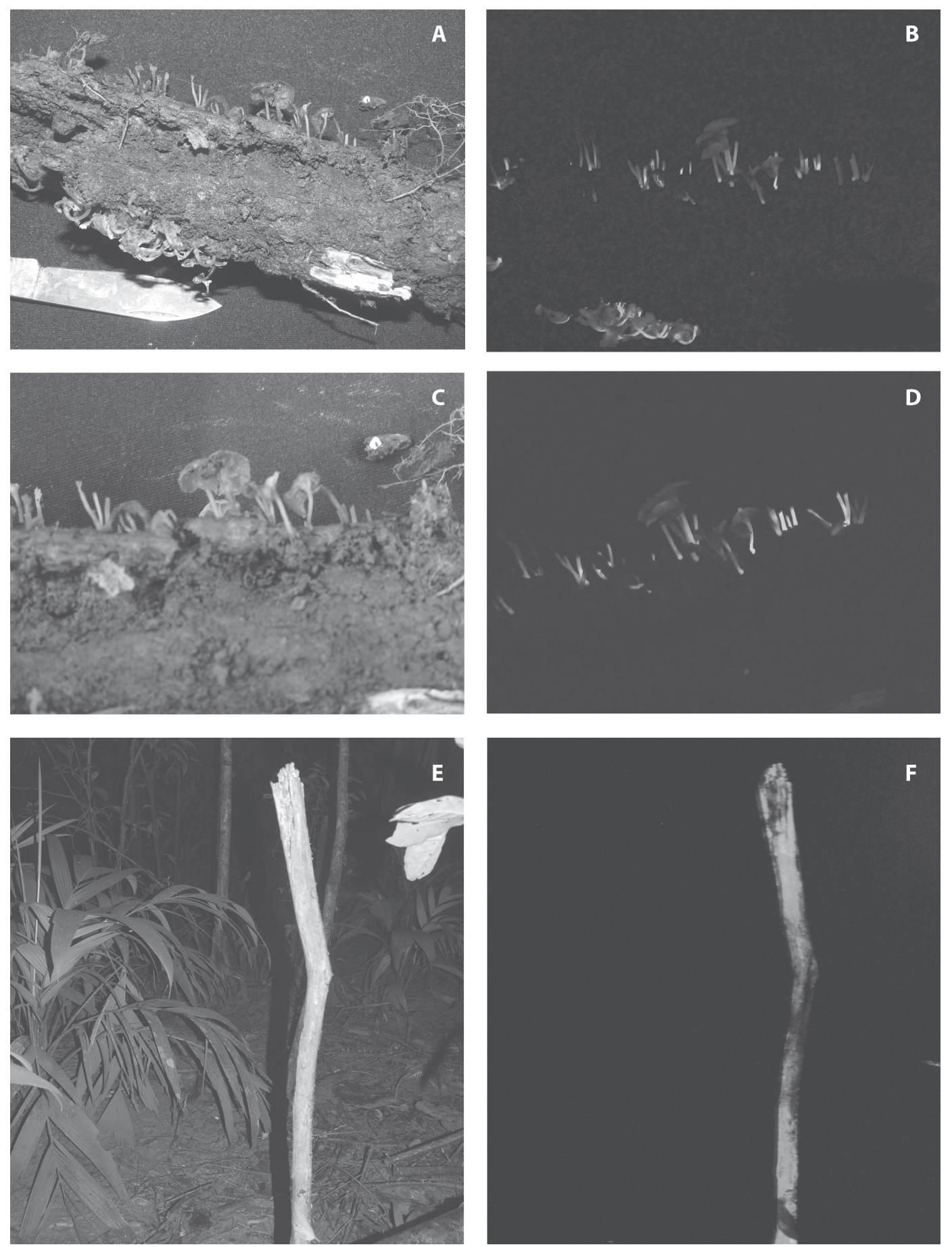

Fig. 2. A. Mycena s.l. 1 (photograph taken in daylight). B. Mycena s.l. 2 (photograph taken in the dark showing bioluminescense). C. Mycena s.l. 2 (photograph taken in daylight). D. Mycena s.l. 2 (photograph taken in the dark showing bioluminescense). E, F. Prefered substrate of the fungi found in this study, (photograph taken in daylight [E] and at night [F]). 
placed in closed plastic bags, which developed fruiting bodies during the same week, although these fruiting bodies did not emit any light at all.

\section{DISCUSSION}

Abundance of bioluminescent fungi: Bioluminescent fungi represent a rare sight in tropical rainforests. Their distribution depends on the nature of the substrates they colonize (Mata 1995, 1997). Fungi from the order Agaricales, which comprise the majority of bioluminescent fungi (Desjardin et al. 2008), are associated with habitat type (Alexopoulus et al. 1996). The two transects with the highest frequency of fungi had fertile soils, creating a higher probability of increased diversity of woody plants, and thus, more substrates for the fungi (which are primarily decomposers of lignin and cellulose). The abundance of bioluminescent fungi at La Selva is certainly influenced by humidity, temperature, exposure to light (Bermudes et al. 1990) and the pervasive presence of streams. For these reasons, the interaction of forest type and soil type explained the distribution of bioluminescence fungi, with soil type as the most important variable.

Field records: The identification of fruiting bodies is still one of the fastest ways to perform fungi identification in the field. Mycena s.l. is very common in tropical rainforests and has been well studied (Mata 1995, 1997, Desjardin et al. 2007). Xylariaceous mycelia have been reported with variable levels of bioluminescence by Shimomura (2011). Harvey (1952 in Weitz 2004) mentioned a possible exception of bioluminescent fungus, Xylaria hypoxilon. The order Xylariales is very specific with respect to substrates types (Lodge 2001), and there could be a possible relationship between this group and Geonoma congesta, or the family Arecaceae in general.

Future work should concentrate on the basic ecology, dispersal, substrate preferences, and temporal cycles in the light emission of fungal mycelia related to weather conditions. Once more information is accumulated, and locating of bioluminescent fungi at night becomes more efficient, we will be able to gather more evidence to understand the role that these organisms play across successional gradients, and how they affect the patterns of diversity of tropical forests in general.

\section{ACKNOWLEDGMENTS}

The authors thank the Costa Rica-USA Foundation and the Organization for Tropical Studies for funding REU for this research. Erin Marnocha and Carlos Rojas made comments that significantly improved the manuscript. Andrés Jiménez and Maricela Pizarro helped in the field, and Gustavo Gutiérrez provided logistical support.

\section{RESUMEN}

La mayoría de las investigaciones sobre los hongos bioluminiscentes se ha centrado en relaciones taxonómicas. Los aspectos básicos de la historia natural y relaciones ecológicas de este grupo son poco conocidos. En este estudio, comparamos la distribución de hongos bioluminiscentes entre el bosque primario y el secundario en la Estación Biológica La Selva, Costa Rica en relación con cuatro tipos de suelo. El estudio se realizó durante la estación lluviosa del 2009. Se buscaron hongos bioluminiscentes en ocho transectos distribuidos de manera uniforme en el bosque primario y secundario y en cuatro tipos de suelo, cubriendo un área de $9420 \mathrm{~m}^{2}$. Se encontraron hongos en cuatro sustratos: arena, ramas caídas, troncos muertos, y raíces muertas, para un total de 61 muestras. Se encontró una relación significativa entre la presencia de hongos y la distribución de los tipos de suelo $\left(\mathrm{x}^{2}=18.89, \mathrm{gl}=9, \mathrm{p}=0.026\right)$. Sólo se encontraron tres muestras con cuerpos fructíferos, dos de ellos del género Mycena, mientras que el otro presentaba un hongo del orden Xylariales (posiblemente Hypoxylon sp. Kretzschmariella sp. Xylaria sp.). Futuras líneas de investigación deben concentrarse en aspectos básicos de la ecología del grupo, tales como su dispersión y preferencia de sustrato. Esta información fomentará una mayor investigación sobre la distribución, la estacionalidad y fenología reproductiva, y los requerimientos ecológicos de este grupo de hongos.

Palabras clave: bioluminiscencia, bosque tropical lluvioso, Costa Rica, hongos, La Selva, Mycena. 


\section{REFERENCES}

Alexopoulus, C.J., C.W. Mims \& M. Blackwell. 1996. Introductory Mycology. John Wiley \& Sons, New York, New York, USA.

Bermudes, D., V.L. Gerlack \& K.H. Nealson. 1990. Effects of Culture Conditions on Mycelial Growth and Luminescence in Panellus stypticus. Mycologia 82: 295-305.

Capelari, M., D.E. Desjardin, B.A. Perry, T. Asai \& C.V. Stevani. 2011. Neonothopanus gardneri: a new combination for a bioluminescent agaric from Brazil. Mycologia 103: 1433-1440.

Deheyn, D. 2007. Bioluminescence characteristics of a tropical terrestrial fungus (Basidiomycetes). Luminescence 22: 462- 467.

Desjardin, D.E., M. Capelari \& C.V. Stevani. 2005. A new bioluminescent agaric from São Paulo, Brazil. Fungal Divers 18: 9-14.

Desjardin, D.E., M. Capelari \& C.V. Stevani. 2007. Bioluminescent Mycena species from São Paulo, Brazil. Mycologia 99: 317-331.

Desjardin, D.E., A.G. Oliveira \& C.V. Stevani. 2008. Fungi bioluminescence revisted. Photoch. Photobio. Sci. 7: 170-182.

Foerster, G.E., P.Q. Behrens \& R.L. Airth. 1965. Bioluminescence and other characteristics of Collybia velutipes. Am. J. Bot. 52: 487-495.

Herring, P.J. 1994. Luminous fungi. Mycologist 8: 181-183.

Lieberman, D. \& M. Lieberman. 1987. Forest Tree growth and dynamics at La Selva, Costa Rica (1969-1982). J. Trop. Ecol. 3: 347-358.

Lodge, D.J. 2001. Diversidad mundial y regional de hongos, p. 291-304. In H.M. Hernández, A.N. Garcia, F. Álvarez \& M. Ulloa (eds.). Enfoques contemporáneos para el estudio de la biodiversidad. Instituto de Biología, UNAM, México.
Mata, M.M. 1995. Estudio Taxonómico de Algunas Familias de Agaricales y Russulales Presentes en Dos Zonas con Bosques de Quercus en Costa Rica. Tesis Licenciatura, Escuela de Biología, Universidad de Costa Rica, San José, Costa Rica.

Mata, J.L. 1997. Estudio Taxonómico y Ecológico de los Hongos Agaricales en el Bosque del Niño, Reserva Forestal de Grecia. Tesis Maestría, Escuela de Biología, Universidad de Costa Rica, San José, Costa Rica.

Matlock, R. \& G. Hartshorn. 1999. La Selva Biological Station (OTS). Bull. Ecol. Soc. Am. 80: 188-193.

McDade, L. \& G. Hartshorn. 1994. Ecology and Natural History of a Neotropical Rain Forest, p: 6-14. In L. McDade, K.S. Bawa, H.A. Hespenheide \& G.S. Hartshorn (eds.) La Selva, Chicago, Chicago, USA.

Mueller, G., F. Bills \& M.S. Foster. 2004. Biodiversity of fungi: inventory and monitoring methods. Elsevier, Oxford, United Kingdom.

O'Kane, D.J., W.L. Lingle, D. Porter \& J.E. Wampler. 1990. Spectral analysis of bioluminescence of Panellus stypticus. Mycologia 82: 607-616.

Peterson, R.H. \& D. Bermudes. 1992. Intercontinental compatibility in Panellus stypticus with a note on bioluminescence. Persoonia 14: 457-463.

Sancho, F. \& R. Mata. 1987. Estudio detallado de los suelos de la Estación Biológica La Selva. Organización para los Estudios Tropicales, San José, Costa Rica.

Shimomura, O. 2011. Bioluminescence: Chemical Principles and Methods. World Scientific, Singapore.

Sivinski, J. 1981. Arthropods attracted to luminous fungi. Psyche 88: 383-390.

Sivinski, J. 1998. Phototropism, Bioluminescence, and the Diptera. Fla. Entom. 81: 282-292.

Weitz, H.J. 2004. Naturally bioluminescent fungi. Mycologist 18: 4-5.

Wilson, T. \& J.W. Hastings. 1998. Bioluminescence. Ann. Rev. Cell. Dev. Bi. 14: 197-230. 
